\title{
EVALUASI KUALITAS NILAI NUTRISI PRODUK SUSU SAPI DI KOPERASI MERAPI SINGGALANG, KOTA PADANG PANJANG SUMATERA BARAT
}

\section{The Quality Evaluation of Nutrient of Milk Cow Products in Merapi Singgalang Cooperative, Padang Panjang City of West Sumatera}

\author{
Yoshi Lia Anggrayni ${ }^{1}$, Imelda Siska ${ }^{1}$, dan Infitria ${ }^{1}$ \\ ${ }_{1}^{1}$ Program Studi Peternakan Fakultas Pertanian Universitas Islam Kuantan Singingi \\ Email: liayoshi.yla@gmail.com
}

\begin{abstract}
ABSTRAK
Penelitian ini bertujuan untuk mengevaluasi kualitas nilai nutrisi olahan susu sapi yang antara lain susu pasteurisasi, es krim, dan keju. Penelitian ini dilaksanakan di Koperasi Merapi Singgalang, Kota Padang Panjang, Sumatera Barat dan Laboratorium Nutrisi Universitas Andalas, Padang. Peubah yang diamati yaitu kadar protein kasar, kadar lemak kasar, bahan kering, dan bahan kering tanpa lemak. Penelitian ini menggunakan metode survey kemudian data dianalisis secara deskripstif dengan menggunakan rumus nilai rata-rata dan simpangan baku. Hasil penelitian menunjukkan bahwa kualitas produk susu pasteurisasi mengandung PK 3,23 \%; LK 3,60 \%; BK 12,56 \%; dan BKTL 8,91\%. Kualitas Es krim mengandung PK 3,00 \%; LK 13,00 \%; BK 38,00 \%; dan BKTL 10,00\% dan kualitas keju mengandung PK 24 \%; LK 32,8 \%; BK 65,00 \%; dan BKTL 11,20 \%. Dari hasil penelitian dapat disimpulkan bahwa kualitas nilai nutrisi produk susu sapi di Koperasi Merapi Singgalang Padang Panjang yang sesuai dengan SNI adalah susu pasteurisasi dan es krim.
\end{abstract}

Kata Kunci: Es Krim, Keju, Nilai Nutrisi, Produk Susu Sapi, Susu Pasteurisasi

\begin{abstract}
This research aims to evaluate the nutrient quality of dairy milk which inclueded pasteurized milk, ice cream, and cheese. This study was conducted in the Cooperative Merapi Singgalang, Padang Panjang City, West Sumatera and Nutrition Laboratory Andalas University. The variables observed were the levels of protein, fat, dry matter, and not fat dry matter. This study applied survey method then data analyzed descriptively by the mean value and standard deviation. The results showed that the nutrient quality of pasteurized milk contained protein $3.23 \%$, fat $3.60 \%$, dry matter $12.56 \%$ and not fat dry matter $8.91 \%$. The nutrient quality of ice cream contained protein $3.00 \%$, fat $13.00 \%$, dry matter $38.00 \%$ and non-fat dry matter $10.00 \%$ and the nutrient quality of cheese contained protein $24 \%$, fat $32.8 \%$, dry matter $65.00 \%$ and non-fat dry matter $11.20 \%$. It can be concluded that the nutrient quality of milk products in the Cooperative Merapi Singgalang Padang Panjang that accordance with SNI was pasteurized milk and ice cream.
\end{abstract}

Keywords: Ice Cream, Cheese, Nutrients Value, Dairy Product, Pasteurized Milk

\section{PENDAHULUAN}

Susu merupakan cairan yang berasal dari hasil pemerahan dari ternak perah, dimana kandungan alaminya tidak dikurangi atau ditambahkan dengan sesuatu bahan lainnya. Susu juga merupakan salah satu sumber protein hewani yang sangat baik untuk pertumbuhan dan perkembangan tubuh manusia selain daging dan telur. Nutrisi yang terkandung dalam susu selain protein adalah lemak, karbohidrat, vitamin dan mineral. Susu dapat dikonsumsi oleh semua usia, baik balita maupun orang dewasa. 
Konsumsi susu tidak terbatas pada satu jenis ternak perah saja. Susu yang dapat kita konsumsi adalah susu sapi, kerbau, kambing, kuda, dan unta, akan tetapi susu dari beberapa jenis ternak tersebut memiliki produksi susu yang bervariasi sehingga ketersediaannya terbatas. Susu yang banyak dikonsumsi dan diolah menjadi beberapa produk serta jumlah produksinya tinggi adalah susu sapi. Produksi susu sapi di Indonesia dari tahun ke tahun semakin meningkat. Pada tahun 2009, produksi susu segar di Indonesia sekitar 827 248,64 ton, kemudian meningkat pada tahun 2019 sekitar 996 442,44 ton (BPS, 2019). Hal ini menunjukkan bahwa konsumsi susu di Indonesia meningkat seiring meningkatnya produksi susu sapi. Peningkatan produksi susu di Indonesia dikarenakan kesadaran masyarakat untuk memenuhi kebutuhan proteinnya dalam kehidupan sehari-hari.

Tidak semua wilayah di Indonesia dapat menghasilkan susu segar khususnya susu sapi. Salah satu wilayah yang produksi susu segarnya cukup tinggi di Pulau Sumatera adalah provinsi Sumatera Barat yaitu sekitar 1081,71 ton (BPS, 2019). Provinsi Sumatera Barat merupakan salah satu provinsi yang memiliki iklim sejuk pada beberapa wilayah dan sangat cocok serta memiliki potensi untuk mengembangkan usaha peternakan ternak perah seperti sapi perah. Usaha peternakan sapi perah yang telah menjadi sebuah koperasi adalah Koperasi Peternak Sapi Perah Merapi Singgalang yang berlokasi di Kota Padang Panjang. Koperasi ini telah menjalin kerjasama dengan pemerintah daerah setempat dalam beberapa tahun untuk membantu meningkatkan penjualan produk susu melalui program makanan tambahan bagi anak TK dan SD. Koperasi ini mengolah berbagai olahan susu seperti susu pasteurisasi, yogurt, kefir, keju, stik susu, permen susu, dan es krim. Penelitian ini bertujuan untuk mengevaluasi kualitas nutrisi produk susu (susu pasteurisasi, yogurt, dan es krim) di Koperasi Merapi Singgalang, Kota Padang Panjang.

\section{METODE}

Penelitian ini dilaksanakan di Koperasi Merapi Singgalang, Kota Padang Panjang, Sumatera Barat dan Laboratorium Nutrisi Universitas Andalas, Padang.

\section{Tahapan Penelitian}

a. Melakukan survey penelitian ke kelompok tani ternak dibawah wadah Koperasi Merapi Singgalang.

b. Mengambil sampel olahan susu (susu pasteurisasi, es krim dan keju)

c. Membawa sampel ke laboratorium untuk dianalisis kualitas kimiawi (kadar protein kasar, lemak kasar, bahan kering, dan bahan kering tanpa lemak).

\section{Rancangan Percobaan}

Rancangan penelitian menggunakan yaitu metode eksperimen dengan mengambil sampel olahan susu (susu pasteurisasi, es krim dan keju). Data dianalisis dengan menghitung nilai rata-rata dan simpangan baku. Parameter yang diamati dalam penelitian ini adalah kadar protein, kadar lemak, bahan kering, dan bahan kering tanpa lemak.

\section{HASIL DAN PEMBAHASAN}

\section{Susu Pasteurisasi}

Pasteurisasi adalah metode pemanasan susu dengan suhu sekitar $60-70{ }^{\circ} \mathrm{C}$ dalam waktu tertentu (biasanya tidak lebih dari 30 menit) dengan maksud agar bakteri patogen mati. Akan tetapi bakteri-bakteri tertentu yang bisa menumbuhkan spora dan tahan panas tidak akan mati pada suhu pasteurisasi. Nilai Nutrisi Susu Pasteurisasi ditampilkan pada Tabel 1. 
Tabel 1. Nilai Nutrisi Susu Pasteurisasi pada Koperasi Merapi Singgalang

\begin{tabular}{lc}
\hline \multicolumn{1}{c}{ Nilai Nutrisi } & Susu Pasteurisasi (\%) \\
\hline Protein Kasar & 3,23 \\
Lemak Kasar & 3,60 \\
BK & 12,56 \\
BKTL & 8,91 \\
\hline
\end{tabular}

Berdasarkan hasil pengujian susu pasteurisasi menunjukkan bahwa kandungan protein kasar yaitu sebesar 3,23\%. Hasil pengujian tersebut memenuhi standar yang ditetapkan oleh SNI (1995) yaitu kadar protein susu pasteurisasi minimal 2,5\%. Hasil pengujian kadar lemak susu pasteurisasi yaitu sebesar 3,60\%, hasil pengujian tersebut memenuhi standar yang ditetapkan oleh SNI (1995) yaitu kadar lemak susu pasteurisasi minimal 2,8\%. Kadar protein dan kadar lemak pada susu dipengaruhi oleh beberapa faktor yaitu pakan, iklim, waktu laktasi (Nurwantoro \& Mulyani, 2005), suhu pengolahan dan metode pengawetan susu yang digunakan.

Bahan kering merupakan komponen susu selain kadar air yang meliputi kadar lemak, kadar protein, kadar laktosa, dan kadar mineral, sedangkan nilai bahan kering tanpa lemak yaitu selisih antara bahan kering dengan kadar lemak susu (Vergi et al., 2015). Hasil pengujian bahan kering susu pasteurisasi yaitu sebesar 12,56\%, hasil pengujian tersebut lebih tinggi dari yang ditetapkan oleh SNI (1995) yaitu bahan kering susu pasteurisasi sebesar 10.5\%. Hasil pengujian bahan kering tanpa lemak susu pasteurisasi yaitu sebesar 8,91\%, hasil pengujian tersebut memenuhi standar yang ditetapkan oleh SNI (1995) yaitu bahan kering tanpa lemak susu pasteurisasi minimal 7.7\%. Bahan kering dan bahan kering tanpa lemak dipengaruhi oleh beberapa faktor seperti pakan, umur, penyakit, masa laktasi, musim, dan komponen penyusun lainnya dalam susu (Wibowo et al., 2013 dan Wulandari et al., 2017).

\section{Es Krim}

Es krim adalah makanan semi padat yang dibuat dengan cara pembekuan tepung es krim atau campuran susu, lemak hewani atau lemak nabati, gula, dan dengan atau tanpa bahan makanan lain dan bahan makanan yang diizinkan. Es krim termasuk dalam golongan pangan fungsional. Pangan fungsional merupakan pangan yang memiliki efek kesehatan lain disamping efek zat gizinya. Nilai gizi es krim sangat tergantung pada nilai gizi bahan bakunya, oleh karena itu untuk membuat es krim yang bermutu tinggi maka nilai gizi bahan baku perlu diketahui dengan pasti. Nilai gizi terbesar pada bahan baku es krim adalah susu (Astawan, 2008). Nilai Nutrisi Es Krim ditampilkan pada Tabel 2.

Tabel 2. Nilai Nutrisi Es Krim pada Koperasi Merapi Singgalang

\begin{tabular}{lc}
\hline \multicolumn{1}{c}{ Nilai Nutrisi } & Es Krim (\%) \\
\hline Protein Kasar & 3,00 \\
Lemak Kasar & 13,00 \\
BK & 38,00 \\
BKTL & 10,00 \\
\hline
\end{tabular}

Berdasarkan hasil pengujian es krim menunjukkan bahwa kandungan protein kasar yaitu sebesar 3,00\%, hasil pengujian tersebut memenuhi standar yang ditetapkan oleh SNI (1995) yaitu kadar protein es krim minimal 2,7\%. Tujuan pengujian kadar protein dalam bahan makanan yaitu menentukan tingkat kualitas protein dipandang dari sudut gizi (Satriani et al., 2018). Hasil pengujian kadar lemak es krim yaitu sebesar $13.00 \%$, hasil pengujian tersebut memenuhi standar yang ditetapkan oleh SNI (1995) yaitu kadar lemak es krim minimal 5,0\%. Tujuan pengujian kadar lemak 
dalam bahan makanan dapat meningkatkan rasa, aroma, kerenyahan, dan membentuk tekstur yang lembut dalam mulut (Mahendradatta dan Tiwali, 2007). Koyo et al. (2016) menyatakan bahwa kadar lemak yang terdapat pada es krim disebabkan oleh pengkristalan lemak pada proses pembuatan es krim yang membentuk fat globule menjadi struktur tiga dimensi yang dapat memerangkap air dan udara sehingga dapat mempengaruhi nilai kadar lemaknya. Nissa (2013) menyatakan bahwa lemak dibutuhkan dalam pembentukan struktur es krim dimana besar globula lemak yang membentuk granula menentukan besarnya ukuran rongga udara. Lemak juga menghasilkan tekstur yang lembut pada es krim dimana lemak yang tersebar merata dengan ukuran yang homogen dan kecil dapat membantu menghasilkan titik leleh yang diinginkan.

Hasil pengujian bahan kering es krim yaitu sebesar 38,00\%, hasil penelitian pengujian tersebut lebih tinggi dari penelitian Badem \& Alpkent (2018) yaitu hasil bahan kering es krim 27,23\%. Bahan kering tinggi memungkinkan proporsi pembentukan kristal air yang lebih sedikit sehingga pencairan lambat, mengurangi kekerasan produk, dan menjadikan es krim dengan tekstur yang lembut sedangkan bahan kering rendah menjadikan pembentukan kristal air yang lebih banyak sehingga pencairan sangat cepat, meningkatkan kekerasan produk, dan menjadikan es krim dengan tekstur tidak lembut (Hatipoğlu \& Türkoğlu, 2020). Hasil pengujian bahan kering tanpa lemak pada es krim yaitu sebesar 10,00\%, hasil penelitian pengujian tersebut sesuai dengan Padaga \& Sawitri (2005) yaitu hasil bahan kering tanpa lemak es krim berkisar antara $9-12 \%$. Bahan kering tanpa lemak menyebabkan adonan es krim menjadi kental.

\section{Keju}

Keju menurut SNI (1992) adalah produk berupa padatan plastis yang diperoleh melalui pengolahan keju cedar dengan penambahan pengemulsi dan pemanasan dengan atau tanpa penambahan bahan tambahan makanan lain yang diizinkan. Nilai Nutrisi Keju ditampilkan pada Tabel 3.

Tabel 3. Nilai Nutrisi Keju pada Koperasi Merapi Singgalang

\begin{tabular}{lc}
\hline \multicolumn{1}{c}{ Nilai Nutrisi } & Keju (\%) \\
\hline Protein Kasar & 24,0 \\
Lemak Kasar & 32,8 \\
BK & 65,00 \\
BKTL & 11,20 \\
\hline
\end{tabular}

Hasil pengujian kadar protein keju yaitu sebesar $24,0 \%$, hasil tersebut tidak jauh berbeda dengan penelitian Margoutomo (2012) yaitu hasil kadar protein keju tanpa perlakuan (tanpa penambahan getah tanaman biduri) yaitu sebesar 23,82\%. Kadar protein keju dipengaruhi oleh protein susu, koagulasi dadih, penambahan asam dan penambahan rennet (Sari et al., 2014). Hasil pengujian kadar lemak keju yaitu sebesar 32.8\%, hasil tersebut lebih rendah dari penelitian Priadi et al. (2018) yaitu hasil kadar protein keju tanpa perlakuan (tanpa penambahan tepung mocaf dan tapioka) yaitu sebesar 45,79\%.

Hasil pengujian bahan kering keju yaitu sebesar $65.00 \%$, hasil pengujian tersebut lebih tinggi dari penelitian Margoutomo (2012) yaitu kandungan bahan kering keju berkisar antara 29,27 30,17\%. Menurut Murti (2004), keju memiliki kandungan minimal 23 gram bahan kering dalam setiap 100 gram. Tinggi rendahnya kandungan bahan kering pada keju terkait dengan mutu standar dan keawetan dari keju tersebut. Hasil pengujian bahan kering tanpa lemak keju yaitu sebesar 11,20\%. Kandungan bahan kering tanpa lemak dipengaruhi oleh aspek kandungan serta perbandingan lemak dan kasein, kandungan laktosa, keberadaan penghambat pertumbuhan bakteri 
asamlaktat seperti antibiotik, dan penyakit pada ambing yang yang menghasilkan susu (Walstra et al.,2006).

\section{KESIMPULAN}

Kesimpulan penelitian didapatkan bahwa kualitas nilai nutrisi produk susu sapi di Koperasi Merapi Singgalang Padang Panjang yang sesuai dengan SNI adalah produk susu pasteurisasi dan es krim.

\section{DAFTAR PUSTAKA}

Astawan, Made. (2008). Sehat dengan Hidangan Hewani. Jakarta: Penebar Swadaya.

Badem, A \& Alpkent, Z. (2018). Production of ice cream with carob bean pekmez (molasses). International Journal of Environment, Agriculture and Biotechnology (IJEAB), 3(1), 28-32.

BPS, (2019). Produksi Susu Segar Menurut Provinsi Tahun 2009-2019. Retrived April, 8, 2020. https://www.bps.go.id/linkTableDinamis/view/id/1083.

Hatipoğlu, A \& Türkoğlu, H. (2020). A research on the quality features of ice cream produced using some fat substitutes. Journal of Food Science and Engineering, 10 (2020), 1-10.

Koyo, Anwar M., Umbang Arif R., \& Agus Bahar R. (2016). Tingkat penggunaan santan kelapa dan tepung ubi hutan (dioscore hispida dennts) pada pembuatan es krim. Media Agrosains, 2(01), $16-24$.

Mahendradatta \& Tiwali. (2007). Jagung dan Diversifikasi Produk Olahannya. Makasar: Masagene Press.

Margoutomo, T L. (2012). Kualitas Fisik dan Kimia Keju Asal Susu Skim dengan Penambahan Getah Tanaman Biduri pada Level yang Berbeda. Skripsi. Surakarta: Universitas Sebelas Maret. Surakarta

Nissa, M. (2013). Pengaruh Konsentrasi Sawi Hijau (Brassica rapa var. Parachinensis L.) serta Konsentrasi Agar terhadap Karakteristik Es Krim Nabati (Mellorine). Skripsi. Malang: Universitas Brawijaya.

Nurwantoro \& Mulyani, S (2005). Dasar Teknologi Hasil Ternak. Semarang: Universitas Diponegero. Padaga, M \& Sawitri, M E. (2005). Es Krim yang Sehat. Surabaya: Trubus Agrisarana.

Priadi, G, Setyoningrum, F, Afiati, F, \& Syarief, R. (2018). Pemanfaatan modified cassava flour dan tepung tapioka sebagai bahan pengisi keju cedar olahan. Jurnal Litbang Industri, 8 (2), 67-76.

Sari, N A, Sustiyah, A, \& Legowo, A. M. (2014). Total bahan padat, kadar protein, dan nilai kesukaan keju mozarella dari kombinasi susu kerbau dan susu sapi. Jurnal Aplikasi Teknologi Pangan, 3(4), 152-156.

Satriani, Sukainah, A, \& Mustarin, A. (2018). Analisis fisiko-kimia es krim dengan penambahan jagung manis dan rumput laut. Jurnal Pendidikan Teknologi Pertanian. 4, 105-124.

SNI. 1992. Syarat Mutu Es Krim. Jakarta: Badan Standarisai Nasional.

SNI. 1995. Standar Mutu Susu Pasteurisasi. Jakarta: Badan Standarisai Nasional.

SNI. 1995. Syarat Mutu Keju Ceddar. Jakarta: Badan Standarisai Nasional.

Vergi, M.D, Suprayogi, T.H. \& Sayhuti, S.M.. (2015). Kandungan lemak, total bahan kering dan bahan kering tanpa lemak susu sapi perah akibat interval pemerahan berbeda. Animal Agriculture Journal. 5 (1), 195-199.

Wibowo, P.A, Astuti T.Y, \& Soediarto, P. (2013). Kajian Total Solid (TS) dan Solid Non Fat (SNF) susu kambing Peranakan Ettawa (PE) pada satu periode laktasi. J. Ilmu Peternakan, 1(1), 214-221. 
Wulandari Z, Taufik, E. \& Syarif, M. (2017). Kajian kualitas produk susu pasterurisasi hasil penerapan rantai pendingin. J. Ilmu Produksi dan Teknologi Hasil Peternakan. 5(3), 94-100.

Walstra P, Wouters JTM, \& Guerts, TJ. (2006). Dairy Science and Technology Handbook. $2^{\text {nd }}$ Ed. USA: Taylor and Francis Group. 